Review

\title{
Going Green and Going Dense: A Systematic Review of Compatibilities and Conflicts in Urban Research
}

\author{
Helena Madureira ${ }^{1, *(D)}$ and Ana Monteiro ${ }^{2}$ \\ 1 Faculty of Arts and Humanities, University of Porto/CEGOT, via Panoramica Edgar Cardoso, \\ 4150-564 Porto, Portugal \\ 2 Faculty of Arts and Humanities, University of Porto/CITTA/CEGOT, via Panoramica Edgar Cardoso, \\ 4150-564 Porto, Portugal; anamt@letras.up.pt \\ * Correspondence: hmadureira@letras.up.pt
}

Citation: Madureira, H.; Monteiro, A. Going Green and Going Dense: A Systematic Review of Compatibilities and Conflicts in Urban Research Sustainability 2021, 13, 10643. https:/ / doi.org/10.3390/su131910643

Academic Editor: Stefano Salata

Received: 11 August 2021

Accepted: 21 September 2021

Published: 25 September 2021

Publisher's Note: MDPI stays neutral with regard to jurisdictional claims in published maps and institutional affiliations.

Copyright: (c) 2021 by the authors. Licensee MDPI, Basel, Switzerland. This article is an open access article distributed under the terms and conditions of the Creative Commons Attribution (CC BY) license (https:/ / creativecommons.org/licenses/by/ $4.0 /)$.

\begin{abstract}
The dilemma of simultaneously promoting the advantages of urban densification and urban liveability, namely the environmental and social benefits of urban green spaces, has been widely acknowledged in the research literature. This paper aims to provide an overview of the current state of evidence on benefits, conflicts and challenges emerging from fostering both urban densification and urban greening aims. A systematic review following the PRISMA guidelines was conducted. Searches for peer-reviewed papers were conducted in Scopus and Web of Science. Our search yielded an initial 357 papers, which were then further sorted and screened to the 117 manuscripts retained and included in this review. The authors systematized the multiple perspectives in which the interactions between urban densification and urban greening have been explored. Moreover, the results revealed a lack of clear agreement about the existence or not of conflicts emerging from fostering both urban densification and urban greening aims, suggesting that the positive or negative interactions are not absolute but depend on the scale or the context on which the studies are conducted. Further research should explore multiple potential mediating variables (e.g., the mediator effect of scale and context) to deepen our understanding of interactions between density and greening.
\end{abstract}

Keywords: urban densification; compact cities; green spaces; urban planning; land use planning

\section{Introduction}

Today, $55 \%$ of the world's population lives in urban areas, a proportion that is expected to increase to $68 \%$ by 2050 [1], which will inevitably result in spatial transformations through processes of expansion and/or densification. The need for sustainable urban development is becoming increasingly important and has been included as a ubiquitous goal in research and urban policies agendas. The United Nations' Sustainable Development Goal 11 (SDG11) presents the broad ambition of "inclusive, resilient and sustainable cities". Additionally, it is particularly acknowledged in the New Urban Agenda, adopted in 2016, which aims to anchor global objectives and orientations for sustainable urban development and represents a milestone in the definition of spatial strategies agreed upon at the global level $[2,3]$. Despite its intrinsic holistic nature, the different dimensions of urban sustainable development are often mobilized individually, producing conceptual frameworks and political goals that may incorporate potential contradictions [4]. One apparent area of friction is given by the interaction of the goal of compact city development and urban greening goals [5], both recurrently referenced in urban sustainable development discourses and policies and, more recently, on climate adaptation and mitigation issues.

Compact cities have been, since the early 1990s, one of the leading global paradigms of sustainable urban development and are globally acknowledged in both research and policy as the favoured development pattern to be applied to present and future urban developments [6-8]. Compact city policies favour development patterns characterized by physical compactness, high-density development, mixed land use and well-functioning 
public transport $[4,9,10]$. Urban densification, i.e., the increase in the ratio of dwelling units or people per land area [11] to accommodate population growth, is therefore a major component of compact city policies. Several environmental, economic, and social benefits are claimed to result from urban densification, including decreasing car dependency, more efficient public transport systems, lower energy use and lower environmental impact on surrounding ecosystems $[12,13]$.

Despite the general agreement about the importance of all these benefits and the increasing popularity of the principle of urban densification, some concerns and criticisms have been expressed about its potential negative impacts. The concentration of people and activities is claimed to possibly promote some drawbacks such as the overuse of infrastructures, social inequity due to the higher cost of land, lower neighbourhood satisfaction, traffic congestion or air pollution $[10,14,15]$. One of the most prominent criticisms focuses precisely on the lack of urban green space in densified urban areas and the removal of green space in urban densification processes [16-19]. In fact, while densification policies contribute to the safeguarding of natural spaces at the regional level, they tend to reduce green areas within urban areas [17].

Urban green is increasingly acknowledged as the main supplier of ecosystem services supporting human well-being in cities [20,21]. Environmental functions of urban green spaces include, for instance, air pollution regulation [22], noise reduction [23] or the process of local climate regulation via reduction of urban air temperature [24,25], which is particularly important for urban climate adaptation strategies. Urban green spaces also offer potential social and cultural benefits. They contribute to improving health and well-being through reduction of negative environmental factors, promotion of mental wellness by providing space for contact with nature, and facilitation of active and passive recreational activities and social interactions [26]. Further, being publicly accessible, the presence and use of urban green spaces can diminish health inequalities [27,28].

The dilemma of promoting simultaneously the advantages of urban densification and urban liveability, namely the environmental and social benefits of green areas, has been discussed under the "compact city paradox" [17,29] or urban planning "wicked problems" [4]. This is particularly worrisome regarding current climate change adaptation and mitigation policies. In fact, despite having been ideally formulated as complementary policy areas, adaptation and mitigation strategies comprise potential competing goals, as far as, on the one hand, urban densification is seen as one of the most promising strategies to respond to mitigation and, on the other hand, urban greening policies are frequently mobilized to respond to climate adaptation goals [30-32].

Although some approaches to both dense and green city planning have been proposed [16,33], there is a consensus about the lack of integrative concepts for research and urban planning practice to approach both dense and green cities [34] and in this way respond to the environmental, social and economic challenges posed by urban development. A comprehensive review of the literature exploring how the links between urban densification and green spaces have been being problematized is therefore warranted to inform future research and planning initiatives. In response, this paper presents findings of a systematic review conducted to extract and synthesize existing knowledge about the possibility of coexistence (compatibility) or the necessity of trade-offs (conflicts) while fostering both densification and greening aims. The key question sustaining the systematic literature review is: What is known from the existing literature about compatibilities and conflicts emerging when simultaneously promoting urban densification and urban greening goals?

\section{Materials and Methods}

We performed a systematic review of studies investigating the interactions between greening and density following the PRISMA procedures [35]. A systematic literature review is a research method and process for identifying and critically appraising relevant research to respond to a specific research question [36]. 


\subsection{Design and Search Procedures}

Two databases, Science Direct and Scopus, were searched in January 2021. After several test searches and discussions on keywords among the research team, a list of keywords was defined in order to cover a broad framework of terms associated with the concepts of urban densification and greening (Table 1). In each database, we combined keywords of each group with "OR" while keywords between groups were combined with "AND". The combination of search words with "AND" between the key groups ensured that we only included papers in this review that explicitly focused on both key concepts. The full search strategy for each database is displayed in Table S1.

Table 1. Keyword combinations of the systematic literature search.

\begin{tabular}{cc}
\hline Urban Greening & Urban Densification \\
\hline green space & compact city \\
\hline green infrastructure & compact urban form \\
\hline green structure & compact city development \\
\hline greenness & compact city design \\
\hline & compact city policy \\
\hline & urban intensification \\
\hline & urban densification \\
\hline & compactness \\
\hline
\end{tabular}

\subsection{Eligibility Criteria}

The search was limited to English peer-reviewed research articles and excluded review articles, letters or editorials because their inclusion would possibly lead to duplicate results. In order to centre the results on the most recent research on the relationship between urban densification and greening, only research articles published after 2000 were considered eligible.

\subsection{Search and Selection Process}

The search returned 357 manuscripts, 169 from Web of Science and 188 from Scopus, which were imported to a bibliography managing software $\left(\right.$ EndNote $\left.{ }^{\circledR}\right)$. Following the elimination of 136 duplicates, 221 items were exported to Microsoft Excel to be screened by two reviewers against eligibility and exclusion criteria. Exclusion criteria were based on the evidence of inclusion of both search dimensions urban densification and greening, since only articles problematizing both these dimensions were included in this review. We performed a two-phase selection process. First, we assessed documents based on title and abstract. Then, we retrieved and reviewed the full text of selected papers. Each author independently assessed articles to check their eligibility. In case of conflicting findings, the interpretations made by individual researchers were discussed until a common understanding was reached and, if not resolved, by involving a third researcher. Following the procedure in Figure 1, the final number of articles reviewed was 117.

\subsection{Studies Classification and Analysis}

For each study, we first retrieved publication attributes (title, authors, year of publication and journal). The study area location and the spatial scale analyzed were also extracted from each article. Moreover, narrative summaries related to the research objectives, problematization and results were included. When the database was completed, articles were grouped into recurring topics in order to facilitate comparison across studies. This classification followed an inductive qualitative analysis of the narrative summaries, in 
which the articles were integrated with recurring themes found in the reviewed literature. The topics were chosen by consensus of the authors and were selected as they represent the key themes in which articles problematize the association of urban densification and urban green space. Finally, these topics were grouped into four major topics in which the interactions between urban densification and urban greening were explored (Table 2).

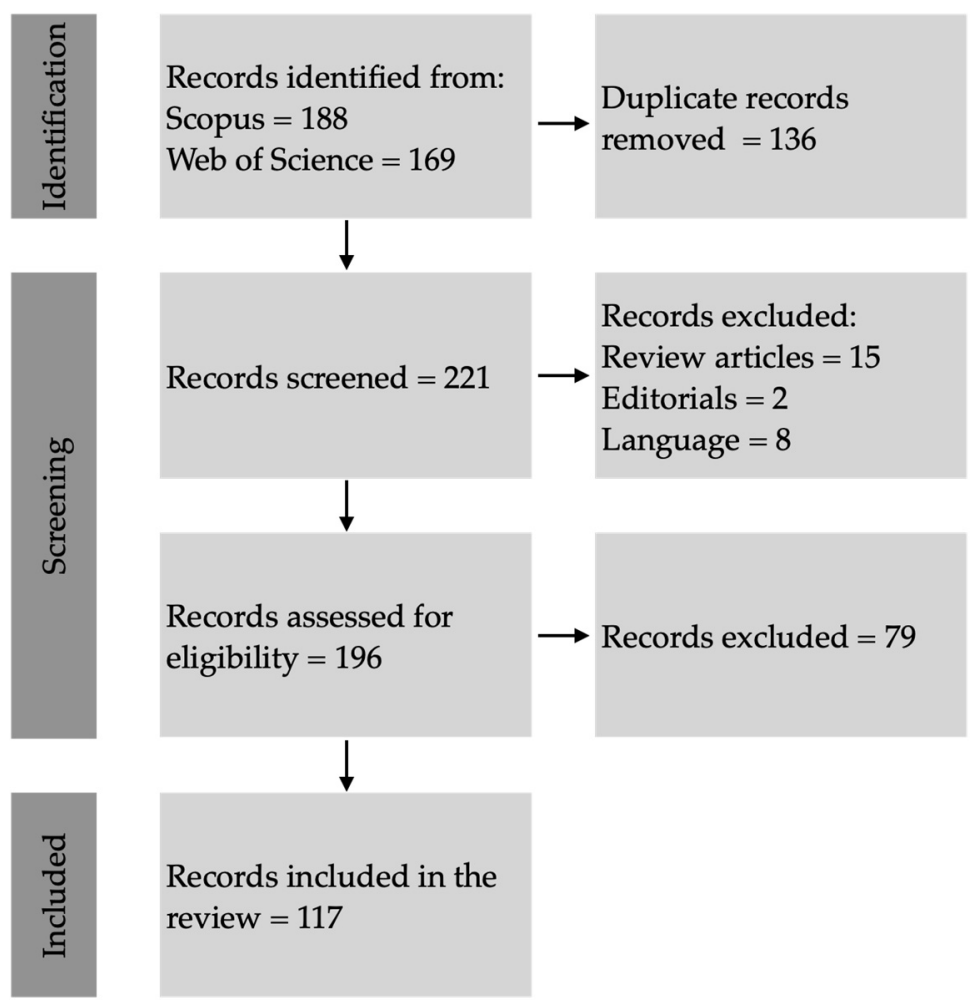

Figure 1. Flow chart of the selection process.

Table 2. Review criteria to analyze papers and extract information.

\begin{tabular}{|c|c|}
\hline Criterion & Classification \\
\hline source & bibliographic information \\
\hline study area location & country/region/city \\
\hline study's objective & narrative summary of the study objective \\
\hline spatial scale & intraurban/city/multi-city/region/country/model \\
\hline objective/results & narrative summary related to the objective/results \\
\hline & green spaces processes and patterns \\
\hline & environmental issues \\
\hline & biodiversity \\
\hline \multirow{10}{*}{ main topic (major/minor) } & ecosystem services \\
\hline & temperature and air pollution \\
\hline & social issues \\
\hline & health and well-being \\
\hline & resident's perspectives \\
\hline & sustainable behaviours and compensation hypothesis \\
\hline & social equity \\
\hline & governance and tools facilitators \\
\hline & policies evaluations and governance challenges \\
\hline & tools and frameworks \\
\hline
\end{tabular}




\section{Results and Discussion}

\subsection{Study Characteristics}

The publication dates for the 117 articles included in this review reflect the rapidly growing interest in recent years in the compatibilization of urban densification and greening policies as a topic among researchers. More than $70 \%(n=84)$ of the articles were published after 2015, showing the current attention researchers are giving to this topic. Most research was conducted in European countries $(n=54)$, reflecting the significant interest in Europe where more compact cities represent certain fixed cultural identities referring to particular mediaeval or early modern urban forms. Nonetheless, there is also huge interest in China $(n=30)$ and a significant awareness in Australia $(n=12)$. The majority of selected studies reported research conducted at city $(n=64)$ or intraurban scales $(n=24)$, and some studies focused on comparative research among cities $(n=19)$. The articles included in this review were published in 55 different journals, underlining the wide spread of research within the topic. Landscape and Urban Planning (15\% of all publications), Sustainability (9\%) and Urban Forestry and Urban Greening (7\%) were the leading journals (Figure 2 and Table S2).
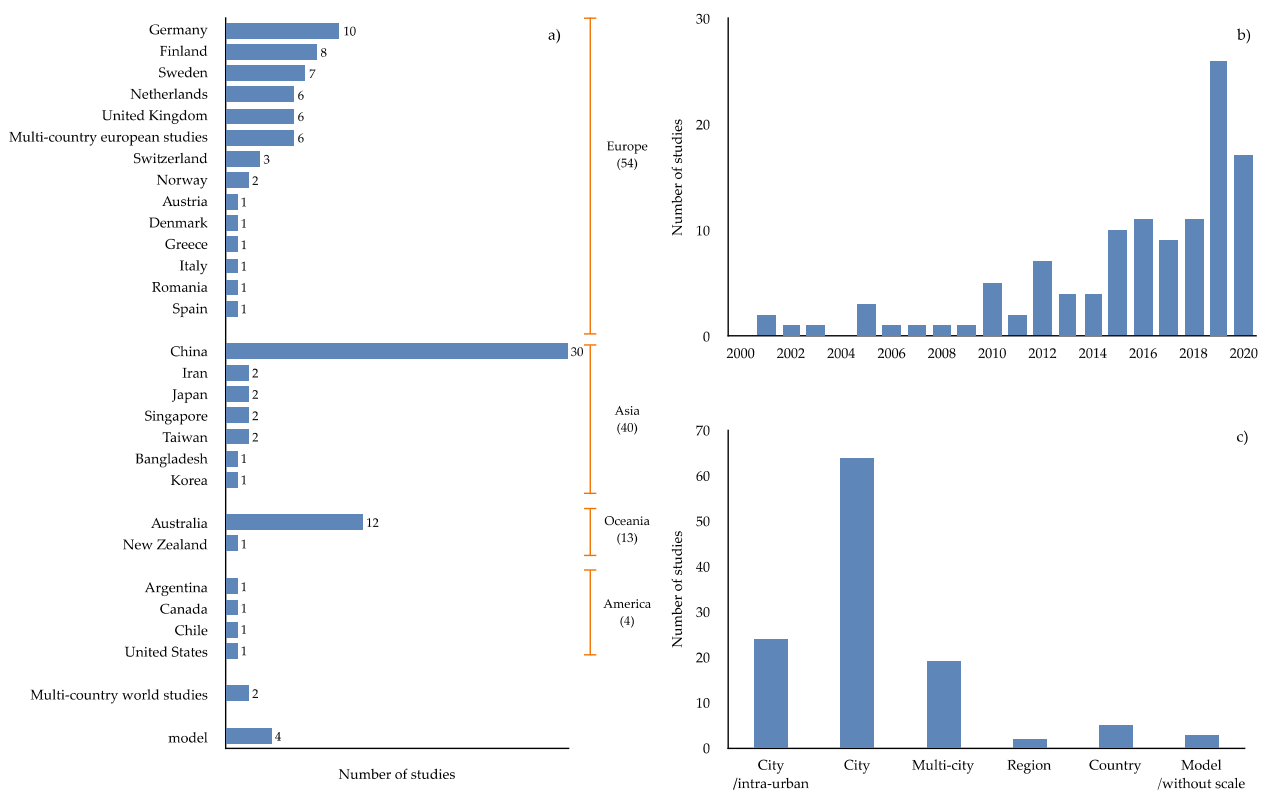

Figure 2. Study characteristics based on (a) the geographic locations of the studies, (b) the number of articles published by year, and (c) the spatial dimension focus of reviewed articles.

The selected studies were wide-ranging in terms of approach, objective and content. Ten different topics of literature problematizing the association of urban densification and urban greening approaches were distinguished in the present review (Figure 3). Major topics of publications were related to social issues (33\%), such as health and well-being, resident perspectives, social equity, sustainable behaviours and compensation hypothesis. Environmental issues, such as biodiversity, temperature/air pollution and ecosystem services, comprised $28 \%$ of the publications. The effect of densification processes and patterns on green spaces was the major topic of about $12 \%$ of the publications. Finally, a significant number of studies focused on policies evaluations (13\%) and on methodological tools or frameworks to foster dense and green cities (21\%). 


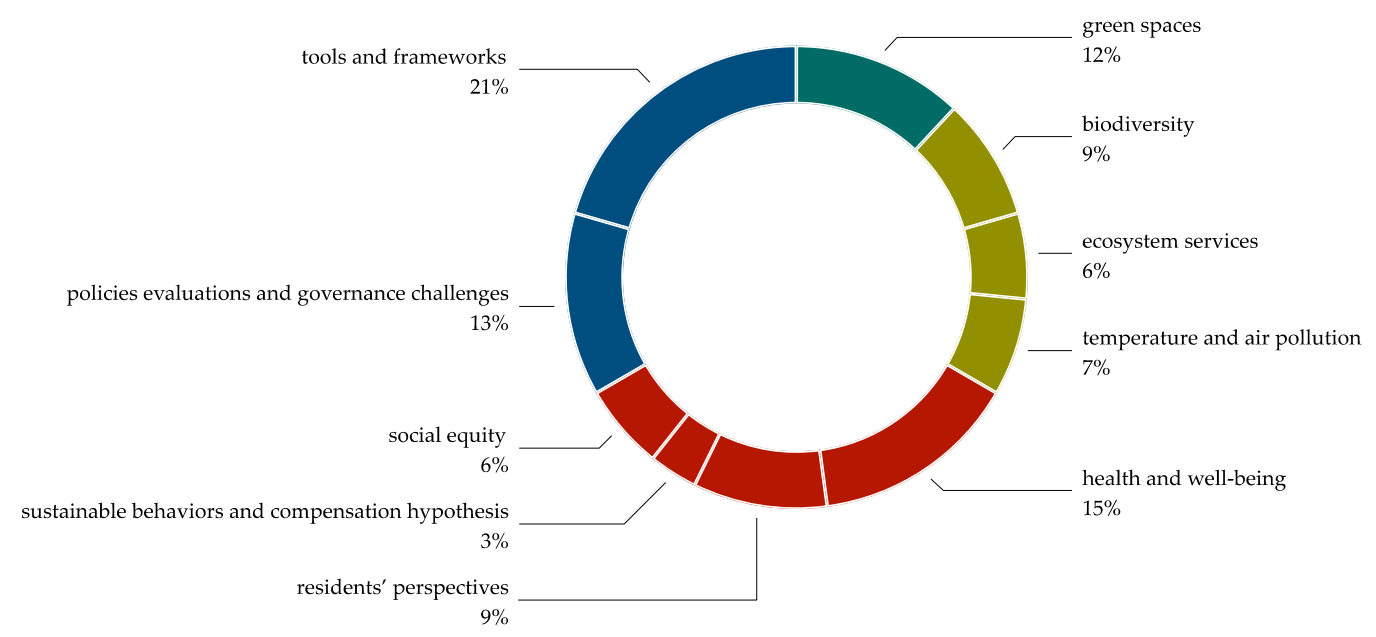

Figure 3. Major topics of literature problematizing the association of urban densification and urban green space.

\subsection{Systematic Literature Review: Qualitative Synthesis}

\subsubsection{Green Spaces}

The studies investigating the effect of densification processes and patterns on green spaces show some contrasting results, challenging the widespread idea of an inevitable loss of urban green space due to densification processes.

The studies exploring spatial relationships between urban form and green spaces, including dimensions such as green spaces' availability, accessibility, ecological quality or connectivity, revealed some divergent results. For instance, it was found that there was insufficient urban green space allocation in the denser areas of Sidney, Australia [37]; Taipei City, Taiwan [38]; and in the Chinese cities of Shanghai [39] and Xiamen [40]. On the other hand, Fan, et al. [41] found a spatial correlation between compactness and green accessibility in the polycentric urban structure of Taipei City and its surrounding outskirts. Studies conducted in Hong Kong show that new town developments, not as compact as the old towns, have not contributed significantly to enhancing ecological quality in urban areas [42] and most residents do not have convenient access to reach parks on foot [43]. Similarly, Tian, et al. [44] points out that, although low connectivity usually occurs in contexts with high building density and low green cover in Hong Kong, urban density may not necessarily have a negative influence on the structural connectivity of green spaces.

Other studies assessed the temporal changes in green spaces coverage among different urban growth patterns. Wang and Yuan [45] evaluated the temporal change of density across 242 Chinese cities and its impacts on multiple indicators of urban greenness, concluding that increasing density reduces per capita park and green spaces. Additionally, Wang, et al. [46], in a study conducted in nine major Chinese cities that became more compact through infill development, found an increase in urban green in urban core areas and loss of urban green in the urban periphery, concluding that although urban green spaces became more evenly distributed, a substantial loss of urban green co-occurred with densification. On the other hand, a study also conducted in China assessing the statistical relationships between urban form metrics and vegetation biomass in the urban expansion area within 10 years for 50 sample cities, shows that compact urban forms yield an average lower vegetation biomass loss caused by urban expansion [47].

The results of these papers seem to claim more scale- and context-comprehensive assessments of the relationships between green spaces and densification processes and patterns. This complexity is well documented in a study evaluating the relation between population and vegetation densities over the past 30 years in the inner city of Berlin, in which it was found that both vegetation and population density may be growing simultaneously, concluding that, at least at city scale, the urban form is not necessarily the only decisive factor in the analysis of a city's green land cover [48]. Additionally, Fuller 
and Gaston [49], by exploring the relationships between urban green space coverage, city area and population size across a large sample of European cities, found that, although, in general, the decline in green space availability per capita accelerates with increasing population density, further increases in density in already compacted urban landscapes do not go along with further reductions in green space provision. Wolff and Haase [14], by systematically mapping the relationship between residential density and green space supply for a large sample of European cities, concluded that there is no single optimal residential density, and turning points are different between cities of different density and location and between different types of neighbourhoods within cities.

\subsubsection{Biodiversity}

Despite the wide recognition of the effects of urbanization processes on biodiversity, the studies investigating the effect of densification on bird communities show some contrasting results. In a study conducted in Santiago, Chile, Amaya-Espinel, et al. [50] found a negative impact of higher building density on the diversity of bird communities around small urban parks, and they also found that the richness and abundance of bird species are related to the size of the park and its distance from the nearest neighbouring green space. Additionally, Ikin, et al. [51] found that overall bird richness and abundance in small urban parks in Canberra, Australia, had consistently negative responses to increasing residential density. On the other hand, on a landscape scale study assessing how receptive different land uses are to the influence of neighbouring green spaces in Leipzig, Andersson, et al. [52] found a statistically significant declining impact of green space on bird species richness outside its boundaries and also that built-up density has a significant impact on the functional footprint of urban green infrastructure; however, they suggested that that, depending on the existence of functional connections, a dense city can provide suitable habitat for specific breeding birds.

Some studies attempt to scenarize the ecological impacts of contrasting urban development models. The negative effects of densification on bird habitats in a moderately urbanized area in Switzerland are underlined by Droz, et al. [53], who applied two scenarios reflecting potential future land use driven by current national and local laws and regulations in Switzerland. In the conservation scenario, an increase was predicted in optimum habitat, and, in contrast, in the scenario based on urban densification, a decrease was predicted in the optimum habitat. Somewhat contradictory results were found in Brisbane, Australia, where simulations of the impact on bird populations of two concrete development scenarios in either compact or sprawling design revealed that, at the city scale, urban growth of any type reduces bird distributions overall, but compact development substantially slows this reduction $[54,55]$. The authors underline the importance of the scale of analysis on studies assessing the effects of urban development patterns on biodiversity, since the ecological impact can be locally intense but spatially constrained, or less intense locally but spatially spread over a more extensive area. The impacts of contrasting urban development models on species richness were also explored by Soga, et al. [56], who quantify the relative conservation benefits of land sharing and land sparing to ground beetles and butterflies in Tokyo. The results of this study show that land-sharing and land-sparing strategies had different impacts on biodiversity and, more remarkably, that these impacts depended strongly on the level of urbanization and the taxa being considered, and thus highlighting the importance of site-specific and taxon-specific assessments.

Tree health seems to be a challenge in already dense city environments. For instance, Chau, et al. [57] assessed the health and structure of urban trees in densely populated public housing estates in Hong Kong, and an important proportion of urban trees were found to have tree defects. Additionally, in Hong Kong, a loss of heritage trees was reported during a ten years evaluation, with the main predisposing causes being injuries sustained in roadwork and construction activities [58]. The same author studied the spatial associations between heritage trees and urban characteristics in Guangzhou (China), concluding that 
increasing compactness may fail to sustain the heritage trees stock and deprive the city of heritage precursors [59].

\subsubsection{Ecosystem Services}

All studies included in this review investigating the relationships between urban form, green coverage and ecosystem services found that, generally, ecosystem performance declined with increasing urban density. In a study focused on temporal changes in 11 contrasting residential sample areas in Merseyside (UK) Pauleit, et al. [60] and Pauleit and Golding [61] found a loss of green spaces in all areas and a consequent negative impact on different ecosystem services. Similarly, Whitford, et al. [62] showed that the greatest influence on ecological performance of four urban areas of Merseyside, UK, was the percentage of green space, particularly trees, concluding that there will be an inevitable trade-off between the ecological performance of compact cities at the regional scale and local levels. In a multiscale assessment of demand and supply of five urban ecosystem services for Berlin, Larondelle and Lauf [63] concluded that the most negative balances of ecosystem services generally overlap the densest and most compact urban structures, highlighting that these results, revealing a "paradox of the compact city", are suggesting new urban design ideas to "shift the paradox into a win-win situation".

However, complex associations between urban density, green coverage and ecosystem performance were also highlighted in some studies. For instance, Tratalos, et al. [64] investigated the relationships between different urban forms and measures of environmental quality and biodiversity potential over 15 sites distributed across five UK cities, concluding that, although most measures of ecosystem performance declined with increasing urban density, there was considerable variability in the relationships, suggesting that for any given urban density, and with appropriate proportion and configuration of green space and tree cover, there is substantial scope for maximizing ecological performance. Similarly, in a study evaluating ecosystem services provided by the different urban typologies in Singapore and Zurich, Grêt-Regamey, et al. [65] concluded that the supply of urban ecosystem services does not increase linearly with green area coverage but is highly dependent on the urban form, namely the type of vegetation around the buildings and the locations of the neighbourhoods. Additionally, Yao, et al. [66] claimed for explicit spatiotemporal analysis of ecosystem services since an evaluation of the ecosystem services supply-demand balance in Shenyang, China was found to be not only spatially heterogeneous but also temporally heterogeneous.

\subsubsection{Temperature and Air Pollution}

Studies relating urban form, green coverage and air pollution were at certain scale inconclusive, mainly due to differences in research design conceptions. For instance, Verani, et al. [67] investigated how urban green spaces can improve air quality in major transportation axis within the city of Thessaloniki, finding a positive relation between building density, urban density and volume of emissions, and also that a dispersed rather than concentrated pattern of green spaces could better help improve cities' environmental quality. On the other hand, some authors explored the dichotomies between air pollution emissions-exposure or concentration-dispersion patterns. Cho and Choi [68] investigated the effects of compact urban development on spatial distribution of air pollution in seven cities in Korea, concluding that urban compactness has both negative and positive effects on air quality, attributed, respectively, to a higher spatial concentration of pollutants resulting from higher inner urban densities and to a higher dispersion of pollutants attributed to an increase in outer green open spaces. Schindler and Caruso [69] developed a theoretical model to estimate trade-offs between traffic-based emissions and exposure resulting from urban form, finding both an increase in emissions with sprawl and an increase in exposure with compactness, highlighting the preservation of open spaces near the city centre as a key for reducing households' exposure in a densified city. Only one study considering simultaneously density and greenness in relation to energy use and carbon emissions was 
found in this review. Ye, et al. [70] found that indicators of urban compactness and of green space and water body connectivity were positively correlated with urban household energy use and carbon emission in Xiamen, China, suggesting that designing cities to be compact with less accessibility to green space and water bodies may increase household energy consumption.

Some studies questioned the general assumption that the promotion of denser urban environments has negative effects on the local climate. For instance, Iizuka, et al. [71] simulated the impact of designed compact city models on the summer thermal environment in a prefecture in a large metropolitan area of Japan in the 2050s, and a temperature increase was found in the urban area due to urban densification, but, on the other hand, it was also found that replacing the withdrawal area with grassland approximately offsets the temperature increase caused by introducing the compact city models. Additionally, Koch, et al. [72], when modelling the impact of a brownfield redevelopment in Leipzig, as part of a urban densification development strategy, found that it affects the local climate on the site itself and on the surrounding neighbourhood, but, with a proper consideration of green infrastructure design, these impacts were not necessarily negative. In a study assessing and comparing the possible impacts of enhancing vertical or horizontal densification at urban scale in Berlin, Straka and Sodoudi [73] found that vertical densification would be the best scenario to increase human thermal comfort, for its cooling ability due to the higher amount of shading, while enhanced horizontal densification would have a negative impact due to an increase in sealed surfaces that would emit additional heat during the night. Additionally, Arghavani, et al. [74] assessed the effect of different greening scenarios on urban heat island and thermal comfort levels in high-density Tehran, concluding that the green roof approach is a more efficient approach than surface vegetation development in this high-density urban context.

\subsubsection{Health and Well-Being}

Several studies evaluating the association between urban form and health were found in this review.

Some studies, mostly focused on physical health outcomes, suggest close associations between dense urban environments with a lack of green spaces and poor health outcomes. For instance, two large-scale studies in multiple European and Chinese cities evaluated the association between urban form elements such as land covers and mortality ratios, finding that dense urban environments with a lack of green land covers were associated with a higher mortality $[75,76]$. Additionally, a study conducted by Xie, et al. [77] in Wuhan, China, found that population density and building density were positively associated with stroke risk and, in contrast, a negative correlation between abundance of public parks and stroke risk, regardless of urban density. Similarly, Cusack, et al. [78] observed positive associations between mothers' exposure to green space and term birth weight, especially in high-density locations in Vancouver and Toronto, Canada. Policies of urban densification, in which there remains little or no incentive for housing developers to provide larger domestic gardens, were also questioned by demonstrating the association between domestic gardens and self-reported general health in England [79] and Melbourne, Australia [80].

However, other studies revealed a more complex association between urban density, green spaces and health outcomes. For instance, some studies suggest that dense urban environments with sufficient green spaces may be associated with better mental health and well-being outcomes. This is the case of two studies conducted in Turku, Finland, that assessed the impact of the built environment, namely children's possibilities for independent mobility and opportunities to access environmental affordances, finding that moderate urban densities associated with the presence of green spaces seem to have childfriendly characteristics by both promoting independent access to meaningful places and good perceived health [81] or the likelihood of liking the place [82]. Additionally, a study conducted in Melbourne exploring differences in streetscape imagery from areas with good and bad perceived health and well-being outcomes, revealed that areas with higher 
self-reported health are characterized by both sufficient green space and compactness of the urban environment [83]. Similarly, in a study based on a household survey and geographical data in Guangzhou, China, Qiu, et al. [84] found that both building density and per capita green area are positively correlated with mental health.

Other studies explored the importance of confounder variables. For instance, Chum, et al. [85] found positive associations between sleep problems and commercial density, residential density and industrial land use, but also that these associations were fully attenuated once traffic levels and self-rated noise were controlled. Fransson and Hartig [86] discussed the value of extending the relationships between built environment and health beyond the primary residence, showing that, among men, leisure home owners had lower odds of early death.

Other studies suggest the importance of site-specific characteristics. For instance, neither a negative health impact of living in the central and most compact parts of the Oslo metropolitan area nor an association between green areas and self-reported health was found by Ihlebæk, et al. [87], suggesting that this may be explained by the easy access to green areas throughout the city of Oslo. Additionally, Kytta, et al. [88] found differences between urban and suburban settings in well-being outcomes related to density and green spaces availability in Helsinki, suggesting for instance that for Finnish residents, the quality of green settings may be more important than the quantity. In a study conducted in Oslo, Mouratidis and Poortinga [89] found that, at the neighbourhood level, social cohesion is negatively associated with neighbourhood density and urban green space, which could be due to increased physical distances between neighbours when green space is too large. In a different approach, some studies explored the restorative quality of residential streetscapes, including the presence of greenery, to offset problems entailed by urban densification. Restoration likelihood was found to rise with an increase in the number of street trees and the presence of flower beds [90] or the presence of window boxes with greenery [91].

\subsubsection{Residents' Perspectives}

Some articles focused on the idea that urban densification or infill development within the framework of compact city policies are often legitimized by environmental arguments but may be contested by residents. Studies exploring the historical developments and stakeholder positions of adjacent green spaces in Amsterdam show that densification projects in which green space is eliminated may face strong opposition by citizens [92,93]. Tensions between municipal attempts to curb sprawl and urban fringe residents' desire to live in the dispersed settlements outside of urban boundaries were also reported by a study conducted in Christchurch, Aotearoa New Zealand [94]. By exploring an urban regeneration process in Vienna, Austria, in which an attractive green space was created, Arnberger [95] found that urban densification around this green space appears to have reduced its perceived recreational quality due to the higher crowding perception among users. In a different approach, Lo and Jim [96] concluded that the crowded urban milieu of Hong Kong may have weakened attitude and perception towards urban nature, and green sites are more appreciated for pragmatic microclimatic and amenity benefits than for less tangible social and high-order environmental benefits (e.g., habitat for wildlife, soil erosion prevention, social interaction with neighbours or symbol of identity).

Two studies investigated whether substitution of private domestic gardens by public green space under urban densification policies may be acceptable from the residents' point of view. In a study assessing the affordances and meanings that people attach to private domestic gardens and public green spaces in Netherlands, Coolen and Meesters [97] found that public and private green spaces have unique combinations of functions and meanings, so they are not just simple substitutes for each other. On the other hand, while assessing gardening satisfaction and use of local open space among smaller and larger blocks in four areas in Perth, Western Australia, Syme, et al. [98] found that small lots affected neither the recreation values of gardens nor the visitation to local parks. 
Other studies suggest that both greenness and density may be seen as positive attributes. In a large study of perceived residential environmental quality among residents in 11 neighbourhoods in Helsinki, Kytta, et al. [99] found that, although the presence of nature dominates as positive quality factor, densely built places also have a clear social value for inhabitants, suggesting that green areas that are not perceived as highly meaningful or attractive for recreation may be potential sites for infill projects. Interestingly, in a study conducted also in Helsinki evaluating citizens' perceptions on unique urban nature, it was found that people prioritize the conservation value of large and isolated urban forests with less surrounding constructed land cover but higher population density [100]. Additionally, Daams and Sijtsma [101], when evaluating property transactions of Dutch households, inferred that, if we interpret the present-day preferences of the Dutch rich as signposts, then we will desire both to live green and to live in or near high-density cities. This complexity of compact-city liveability was also explored by Kotulla, et al. [102] in a study in North Rhine-Westphalia state in Germany, in which both proximity to green spaces and easy access to local services/facilities and public transportation were considered as key elements for improving compact-city liveability by real-estate experts.

\subsubsection{Sustainable Behaviours and Compensation Hypothesis}

Some studies evaluated the hypothesis of residents living in dense urban environment compensate for the relative lack of green spaces and outdoor leisure opportunities in their residential area by traveling to second homes or other leisure destination. For instance, in Finland, a statistical relationship was found between residential characteristics, namely greater building density and reduced access to a private garden and second home use [103]. Additionally, Grosse, et al. [104] found that people living in a central urban district in Copenhagen, Denmark, go more frequently on longer weekend, holiday and plane trips and choose more distant destinations compared to people living in a small town in the commuter belt. The association between neighbourhood greenness and the number of leisure trips was also verified in Helsinki, but not in Reykjavik [105]. The complexity of the relationships between urban form and sustainable behaviours was also explored by Lo [106], showing that everyday sustainable behaviours across 24 selected OECD cities or metropolitan areas are almost a function of personal factors, whereas the effects of contextual factors related to urban form are not clear.

\subsubsection{Social Equity}

The uneven distribution of urban green space over cities and the hypothesis of an association between urban areas with lower socioeconomical status and lower access to green space benefits were explored by some studies in this review. For instance, studies conducted in an Australian suburban context under densification show that comparatively disadvantaged residents, despite their vulnerability to heat stress, are not more concerned about climate change and are less likely to perceive the benefits of urban greening $[107,108]$. Moreover, some studies hypothesized that an increase in urban density might result in the increased perceived value attached to urban parks, which may induce or reinforce social inequities. Studies conducted in Hong Kong revealed that, compared with other landscape elements, neighbourhood parks induced the heaviest investment intention in home-buying behaviour [109] and that residents would be willing to pay to recover losses of urban green space [110].

The mediating effects of different types of green spaces were also explored in some studies. For instance, for the high-density city of Shanghai, China, a mediating effect was reported of privately supplied green space on the relationship between urban public green space and property value [111]; these results were in line with Lin, Meyers and Barnett [37], who found that urban densification reduces private residential tree cover, which disproportionately affects disadvantaged communities, which therefore tend to have a greater reliance on public green infrastructure. Additionally, Lin, et al. [112] concluded in a study conducted in Brisbane, Australia, that people living in more advantaged neigh- 
bourhoods, with a higher vegetation cover and a greater nature relatedness, may receive greater ecosystem services benefits from their yards via both passive and active means. In a complementary result, Baro, et al. [113] found that trees can play an important redistributive role in relation to the local provision of ecosystem services due to the generally uneven distribution of other urban green infrastructure components such as urban forests, parks or gardens in compact cities such as Barcelona.

\subsubsection{Policies Evaluations and Governance Challenges}

Some studies evaluated the results of implemented policies promoting urban densification. A comparison of urban spatial development strategies among a large sample of European cities showed that most cities progressed towards compact and functional mix patterns, but almost none halted land taking, and only in a few cases achieved a higher population density co-occurring with enhancing green space availability [2]. Additionally, Dallimer, et al. [114] documented a decline in green space coverage in 13 English cities, coincident with policy reforms that favoured densification. Urban policies were considered insufficient to mitigate the negative outcomes of densification on urban green coverage in Amsterdam [5] and Hong Kong [115,116]. Hansen, Olafsson, van der Jagt, Rall and Pauleit [33] surveyed 20 European cities to evaluate how urban planning practices currently promote green spaces' multifunctionality in increasingly compact cities, finding a general awareness of the multiple functions of urban green infrastructure and of the relevance of multifunctionality enhancement under densification contexts, but they also found some limitations regarding the application of comprehensive approaches to planning multifunctionality.

Institutional constraints related to the implementation of urban densification in planning practices, while simultaneously providing sufficient green spaces, are also acknowledged in some studies included in this review. Challenges involving green space planning and management practices in urban contexts undergoing densification were explored in Stockholm, Sweden [117], and Helsinki, Finland [118], showing that, although the political demand for increasing density seems to create a growing need for incorporating the green infrastructure or ecosystem services concepts into policy frameworks, the professionals still identify many remaining challenges linked to integrating these concepts into land-use planning. Additionally, studies conducted in Stockholm, Sweden [12], and Greater Melbourne and Victoria, Australia [119], documented the challenges identified by municipal planners, namely site-specific conditions for densification projects, conflicting interests between beneficiated and affected actors, green quality management issues and limited use of impact assessment tools.

Some studies evaluated how the current emphasis on compact city policies may lead to redefining and reshaping the urban green planning visions in cities. Hautamaki [120] shows that green planning principles have been reshaped to coincide with densification policies in Helsinki, arguing that the multidimensional nature of urban green is being reduced to qualities that correspond to a hegemonic urban vision, namely intensively maintained urban parks. Additionally, Uggla [121] explored the urban densification narratives in Stockholm, showing that nature is arranged in an orderly fashion to meet the needs of citizens, narrowing the scope for what kind of nature and what species can be tolerated in the city. Additionally, Tappert, Kloti and Drilling [18] advocated that the normative construction of the compact city constitutes a hegemonic spatial order that turns urban allotment gardens into contested space in Swiss cities.

The development of new forms of governance to foster urban densification and greening agendas was also acknowledged by the studies included in the present review. Nikolaidou, et al. [122] showed that, as a consequence of urban densification processes in Geneva, Switzerland, more flexible, informal and adaptive forms of urban gardening are emerging at the local neighbourhood level, which claims for new forms of participation and cooperation between civil society and political-administrative actors in urban governance. Assuming that for implementing a densification and greening urban agenda, politicians 
and policymakers had to be convinced of its values as well as its potential of realistic realization, Tillie, et al. [123] discussed the promising results of a transition management approach applied in Rotterdam, combining urban data, modelling and design throughout the process.

\subsubsection{Tools and Frameworks}

Finally, a large number of studies included in this review explored methodological frameworks or tools to foster dense and green cities, namely by facilitating the management of trade-offs between urban densification and the provision of green space, such as urban development models and scenarios [124-133], frameworks for multiscale or multicriteria assessment of green spaces in the context of urban densification [134-140], frameworks to optimize vertical gardening, green roofs or sky gardens [141-146], or new tools for understanding and measuring how urban design affects green space accessibility [147].

\section{Discussion}

This study examined research addressing the interactions between urban densification and urban greening. Specifically, a literature search was undertaken using the ISI Web of Science and Scopus databases for the period 2000-2020, resulting in 117 articles whose full text was reviewed and assessed. We systematized the multiples perspectives in which the interactions between urban densification and urban greening have been explored, which can be summarized in four main groups: (i) green spaces' processes and patterns, including spatial relationships between urban form and green coverage and temporal changes in green spaces' attributes among different urban growth patterns; (ii) social issues, including health and well-being outcomes, residents' perspectives and acceptance of urban densification and urban greening changes, or sustainable behaviours such as compensation actions; (iii) environmental issues, including studies on temperature, air pollution, biodiversity and ecosystem services; (iv) governance and tools facilitators, including studies on implemented policies or new forms of governance and tools and methodological frameworks to foster both dense and green cities, namely by facilitating the management of trade-offs between urban densification and the provision of green space.

Above all, this review demonstrates the lack of a clear agreement about compatibilities and conflicts that may be revealed while fostering both urban densification and urban greening aims. This lack of agreement is shown in this review, at a first glance, by the imbalanced distribution of positive and negative interactions among the different considered topics. Additionally, it is especially demonstrated by a dichotomy between positive and negative interactions under the same topic. For example, the results of this review show that the interaction of urban densification and urban greening aims may produce both positive and negative effects on green spaces' processes and patterns and on biodiversity. Moreover, these uncertainties are emphasized by the fact that in almost all the considered topics, studies were found reporting that the positive or negative interactions between urban densification and urban greening are not absolute but depend on the scale or the context on which the studies were conducted. For instance, the studies investigating the effect of densification processes on green spaces show contrasting results, as, although the loss of urban green space was the most prevalent result, it was also reported that depending on scale, context or densification intensity, both vegetation and population density may grow simultaneously. Therefore, the results revealed important findings and also offer some insights on how to approach dense and green cities at the same time (Figure 4). 


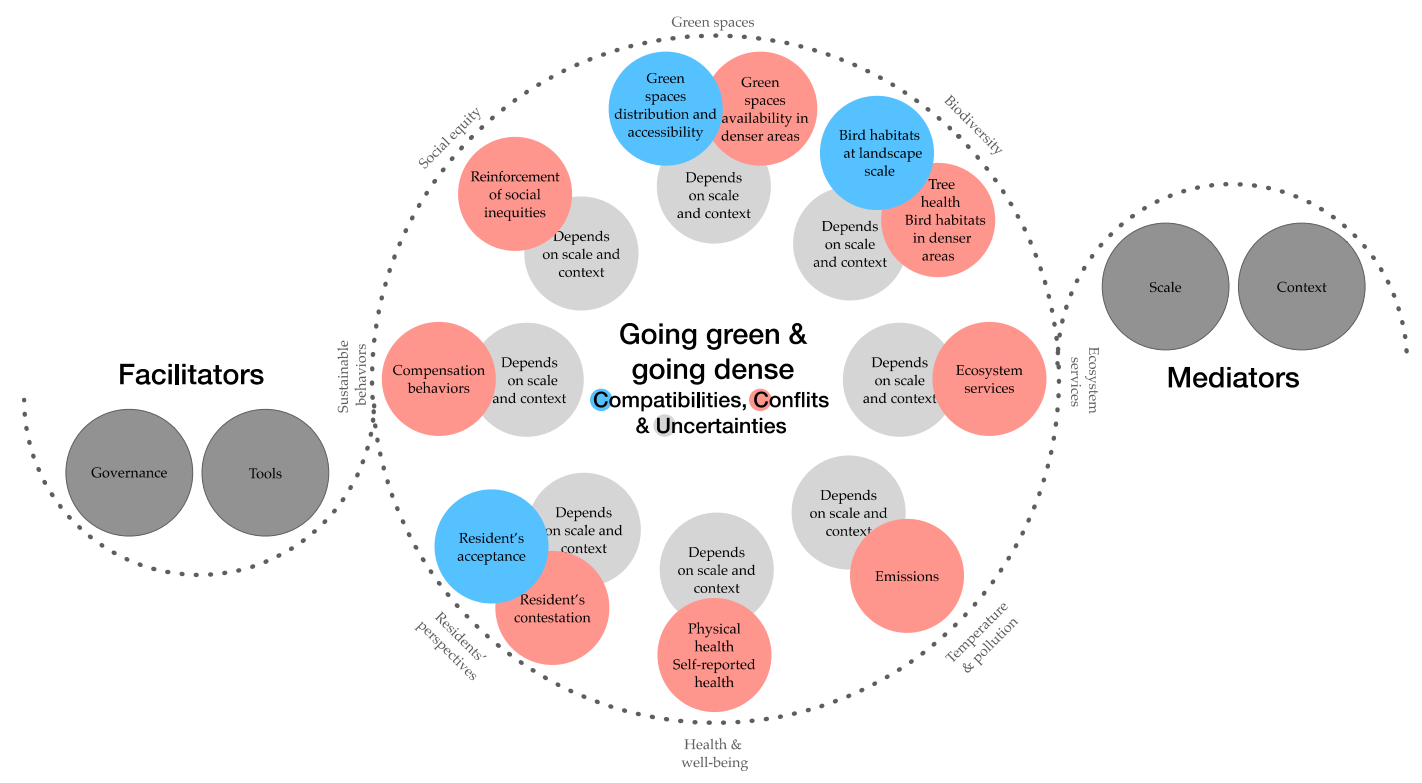

Figure 4. Graphical representation of the reviewed literature results problematizing the association of urban densification and urban greening.

Firstly, the scale and the context seem to be not only key mediator factors, explaining positive or negative interactions between greening and densification, but also key variables to be considered to approach dense and green cities at the same time. The results of this systematic review confirm the spatial scale as a factor of high relevance to assess and manage the interactions between urban density and urban greening $[4,16,17,34]$. In fact, dense developments at the scale of a neighbourhood, a town, a city or metropolitan area can have manifestly different social, ecological and economic outcomes [148]. Furthermore, since the patterns, dynamic and degree of land uses can radically differ between scales, the positive or negative interactions between greening and densification can differ considerably between small and large units [34]. This is especially important as certain dense developments may be beneficial at city scale and simultaneously have negative impacts at the local scale; for instance, in denser cities, traffic-based emissions are usually lower at the city scale but individual exposures may be highest in its denser areas [69]. On the other hand, the results of this systematic review also show that positive or negative interactions between density and greening are intimately associated with the context in which these interactions occur. The relationships between urban density and greenness vary somewhat across cities, depending on the local socioeconomic, functional and morphological context. Moreover, a city does not necessarily follow a single development paradigm such as the compact or the dispersed city, so cities are frequently a combination of contrasting spatial development patterns [48]. Additionally, the relationships between urban density and greenness are intensely meditated by the quality factor, given the established idea that high-quality green spaces or green infrastructures can compensate for the quantitative lack of green space [17]. Multiscale and multidimensional approaches are therefore fundamental to the pursuit of dense and green cities goals.

Secondly, renovated tools and forms of governance seem to be fundamental facilitators to optimize multiscale and multidimensional approaches to dense and green cities. The results of this systematic review show that a large amount of research has been performed to propose methodological frameworks or tools to foster dense and green cities, namely by facilitating the management of conflicts between urban densification and the provision of green space. However, further research is needed in order to fulfill the high demands of managing the complex interactions between compact and green development [34]. In fact, the high complexity of urban systems calls for holistic multidimensional and multiscale frameworks able to support the assessment of the relationships between the built and green 
components [16]. Moreover, although local approaches can be developed by learning from other cities, they must be grounded on a clear understanding of the local factors, namely compatibilities and conflicts that may be revealed in the specific local contexts [2]. Therefore, more research is needed to help urban planners facing the wicked problems related to dense vs. green cities, namely by providing tools enabling multiscale and multidimensional approaches grounded in local qualitative and quantitative data $[2,16]$. Renovated forms of governance, enabling cross-sectoral and cross-scalar planning operations and stakeholder engagement across different sectors are therefore also essential for adopting an integrated governance approach that enhances densification-greening compatibility [16].

\section{Conclusions}

This study systematized the multiple perspectives in which the interactions between urban densification and urban greening have been being explored during the last two decades. One immediate conclusion is the increasing awareness among researchers about the importance of pursuing both of these aims. However, the results of this literature review also showed a lack of a clear agreement about compatibilities and conflicts that may be revealed while fostering both urban densification and urban greening aims. These shortcomings and gaps clearly indicate opportunities for further research:

- Further research should enrich the scope of evidence by providing insights into local policy experiences. Although the hypothetical inclusion of grey literature could have resulted in research-quality concerns, including those related to the interpretation of reports in different languages, the exclusive use of research published in peerreviewed journals contained in two exclusive databases may be seen as a potential limitation of this review.

- $\quad$ Further research should explore multiple potential mediating variables (e.g., the scale and context mediator effect or the governance facilitator effect) in order to deepen our understanding of interactions between density and greening. More research is needed to specifically examine the role of each of these factors in explaining positive or negative interactions between density and greening.

Supplementary Materials: The following are available online at https:/ /www.mdpi.com/article/10 .3390/su131910643/s1, Table S1: Search strings in WOS and Scopus used in this review, Table S2: Included studies in the systematic review.

Author Contributions: H.M.: Conceptualization, Methodology, Investigation, Writing-Original Draft Preparation, Writing-Review and Editing; A.M.: Conceptualization, Methodology, Investigation, Writing-Review and Editing. All authors have read and agreed to the published version of the manuscript.

Funding: This research received support from the Centre of Studies in Geography and Spatial Planning (CEGOT), funded by national funds through the Foundation for Science and Technology (FCT) under the reference UIDB/04084/2020.

Conflicts of Interest: The authors declare no conflict of interest.

\section{References}

1. United Nations. World Urbanization Prospects 2018; United Nations/Department for Economic and Social Affairs: New York, NY, USA, 2019.

2. Cortinovis, C.; Haase, D.; Zanon, B.; Geneletti, D. Is urban spatial development on the right track? Comparing strategies and trends in the European Union. Landsc. Urban Plan. 2019, 181, 22-37. [CrossRef]

3. United Nations General Assembly. New Urban Agenda-Quito Declaration on Sustainable Cities and Human Settlements for All. Available online: https:/ / habitat3.org/the-new-urban-agenda. (accessed on 1 November 2020).

4. Bibri, S.E.; Krogstie, J.; Kärrholm, M. Compact city planning and development: Emerging practices and strategies for achieving the goals of sustainability. Dev. Built Environ. 2020, 4, 100021. [CrossRef]

5. Giezen, M.; Balikci, S.; Arundel, R. Using remote sensing to analyse net land-use change from conflicting sustainability policies: The case of Amsterdam. ISPRS Int. J. Geo-Inf. 2018, 7, 381. [CrossRef] 
6. European Commission. Cities of Tomorrow: Challenges, Visions, Ways Forward; Publications Office of the European Union: Luxembourg, 2011.

7. OECD. Compact city policies: A comparative assessment. In OECD Green Growth Studies; OECD: Paris, France, 2012.

8. Commission of the European Communities. Green Paper on the Urban Environment; Office for Official Publications of the European Communities: Brussels, Belgium, 1990; Volume 12902.

9. Newman, P.; Kenworthy, J. Sustainable urban form: The big picture. In Achieving Sustainable Urban Form; Williams, K., Burton, E., Jenks, M., Eds.; Spon Press: London, UK, 2000; pp. 109-120.

10. Burton, E. The compact city: Just or just compact? A preliminary analysis. Urban Stud. 2000, 37, 1969-2006. [CrossRef]

11. Bibri, S.E. Compact urbanism and the synergic potential of its integration with data-driven smart urbanism: An extensive interdisciplinary literature review. Land Use Policy 2020, 97, 104703. [CrossRef]

12. Khoshkar, S.; Balfors, B.; Wärnbäck, A. Planning for green qualities in the densification of suburban Stockholm-Opportunities and challenges. J. Environ. Plan. Manag. 2018, 61, 2613-2635. [CrossRef]

13. Lemoine-Rodríguez, R.; Inostroza, L.; Zepp, H. The global homogenization of urban form. An assessment of 194 cities across time. Landsc. Urban Plan. 2020, 204, 103949. [CrossRef]

14. Wolff, M.; Haase, D. Mediating sustainability and liveability-Turning points of green space supply in European cities. Front. Environ. Sci. 2019, 7. [CrossRef]

15. Williams, K. Does intensifying cities make them more sustainable. In Achieving Sustainable Urban Form; Spon Press: London, UK, 2000; pp. 30-45.

16. Artmann, M.; Kohler, M.; Meinel, G.; Gan, J.; Ioja, I.-C. How smart growth and green infrastructure can mutually support each other-A conceptual framework for compact and green cities. Ecol. Indic. 2019, 96, 10-22. [CrossRef]

17. Haaland, C.; van den Bosch, C.K. Challenges and strategies for urban green-space planning in cities undergoing densification: A review. Urban For. Urban Green. 2015, 14, 760-771. [CrossRef]

18. Tappert, S.; Kloti, T.; Drilling, M. Contested urban green spaces in the compact city: The (re-)negotiation of urban gardening in Swiss cities. Landsc. Urban Plan. 2018, 170, 69-78. [CrossRef]

19. Næss, P.; Saglie, I.-L.; Richardson, T. Urban sustainability: Is densification sufficient? Eur. Plan. Stud. 2020, 28, 146-165. [CrossRef]

20. Tzoulas, K.; Korpela, K.; Venn, S.; Yli-Pelkonen, V.; Kaźmierczak, A.; Niemela, J.; James, P. Promoting ecosystem and human health in urban areas using Green Infrastructure: A literature review. Landsc. Urban Plan. 2007, 81, 167-178. [CrossRef]

21. Van den Berg, M.; Wendel-Vos, W.; van Poppel, M.; Kemper, H.; van Mechelen, W.; Maas, J. Health benefits of green spaces in the living environment: A systematic review of epidemiological studies. Urban For. Urban Green. 2015, 14, 806-816. [CrossRef]

22. Abhijith, K.V.; Kumar, P.; Gallagher, J.; McNabola, A.; Baldauf, R.; Pilla, F.; Broderick, B.; Di Sabatino, S.; Pulvirenti, B. Air pollution abatement performances of green infrastructure in open road and built-up street canyon environments- A review. Atmos. Environ. 2017, 162, 71-86. [CrossRef]

23. Van Renterghem, T.; Forssén, J.; Attenborough, K.; Jean, P.; Defrance, J.; Hornikx, M.; Kang, J. Using natural means to reduce surface transport noise during propagation outdoors. Appl. Acoust. 2015, 92, 86-101. [CrossRef]

24. Gill, S.E.; Handley, J.F.; Ennos, A.R.; Pauleit, S. Adapting cities for climate change: The role of the green infrastructure. Built Environ. 2007, 33, 115-133. [CrossRef]

25. Bowler, D.E.; Buyung-Ali, L.; Knight, T.M.; Pullin, A.S. Urban greening to cool towns and cities: A systematic review of the empirical evidence. Landsc. Urban Plan. 2010, 97, 147-155. [CrossRef]

26. Markevych, I.; Schoierer, J.; Hartig, T.; Chudnovsky, A.; Hystad, P.; Dzhambov, A.M.; de Vries, S.; Triguero-Mas, M.; Brauer, M.; Nieuwenhuijsen, M.J.; et al. Exploring pathways linking greenspace to health: Theoretical and methodological guidance. Environ. Res. 2017, 158, 301-317. [CrossRef]

27. Kabisch, N.; Strohbach, M.; Haase, D.; Kronenberg, J. Urban green space availability in European cities. Ecol. Indic. 2016, 70, 586-596. [CrossRef]

28. Wolch, J.R.; Byrne, J.; Newell, J.P. Urban green space, public health, and environmental justice: The challenge of making cities 'just green enough'. Landsc. Urban Plan. 2014, 125, 234-244. [CrossRef]

29. Neuman, M. The compact city fallacy. J. Plan. Educ. Res. 2005, 25, 11-26. [CrossRef]

30. Landauer, M.; Juhola, S.; Klein, J. The role of scale in integrating climate change adaptation and mitigation in cities. J. Environ. Plan. Manag. 2019, 62, 741-765. [CrossRef]

31. Sharifi, A. Co-benefits and synergies between urban climate change mitigation and adaptation measures: A literature review. Sci. Total Environ. 2021, 750, 141642. [CrossRef]

32. Grafakos, S.; Trigg, K.; Landauer, M.; Chelleri, L.; Dhakal, S. Analytical framework to evaluate the level of integration of climate adaptation and mitigation in cities. Clim. Change 2019, 154, 87-106. [CrossRef]

33. Hansen, R.; Olafsson, A.S.; van der Jagt, A.P.N.; Rall, E.; Pauleit, S. Planning multifunctional green infrastructure for compact cities: What is the state of practice? Ecol. Indic. 2019, 96, 99-110. [CrossRef]

34. Artmann, M.; Inostroza, L.; Fan, P. Urban sprawl, compact urban development and green cities. How much do we know, how much do we agree? Ecol. Indic. 2019, 96, 3-9. [CrossRef]

35. Moher, D.; Liberati, A.; Tetzlaff, J.; Altman, D.G.; The, P.G. Preferred Reporting Items for Systematic Reviews and Meta-Analyses: The PRISMA Statement. PLoS Med. 2009, 6, e1000097. [CrossRef] 
36. Liberati, A.; Altman, D.G.; Tetzlaff, J.; Mulrow, C.; Gøtzsche, P.C.; Ioannidis, J.P.A.; Clarke, M.; Devereaux, P.J.; Kleijnen, J.; Moher, D. The PRISMA Statement for Reporting Systematic Reviews and Meta-Analyses of Studies That Evaluate Health Care Interventions: Explanation and Elaboration. PLoS Med. 2009, 6, e1000100. [CrossRef] [PubMed]

37. Lin, B.; Meyers, J.; Barnett, G. Understanding the potential loss and inequities of green space distribution with urban densification. Urban For. Urban Green. 2015, 14, 952-958. [CrossRef]

38. Chang, H.S.; Chen, T.L. Decision making on allocating urban green spaces based upon spatially-varying relationships between urban green spaces and urban compaction degree. Sustainability 2015, 7, 13399-13415. [CrossRef]

39. Li, W.F.; Bai, Y.; Zhou, W.Q.; Han, C.M.; Han, L.J. Land use significantly affects the distribution of urban green space: Case study of Shanghai, China. J. Urban Plan. Dev. 2015, 141, A4014001. [CrossRef]

40. Sun, C.; Lin, T.; Zhao, Q.; Li, X.; Ye, H.; Zhang, G.; Liu, X.; Zhao, Y. Spatial pattern of urban green spaces in a long-term compact urbanization process-A case study in China. Ecol. Indic. 2019, 96, 111-119. [CrossRef]

41. Fan, P.; Lee, Y.C.; Ouyang, Z.; Huang, S.L. Compact and green urban development-Towards a framework to assess urban development for a high-density metropolis. Environ. Res. Lett. 2019, 14, 115006. [CrossRef]

42. Tian, Y.H.; Jim, C.Y.; Wang, H.Q. Assessing the landscape and ecological quality of urban green spaces in a compact city. Landsc. Urban Plan. 2014, 121, 97-108. [CrossRef]

43. Tian, Y.H.; Jim, C.Y.; Liu, Y.Q. Using a spatial interaction model to assess the accessibility of district parks in Hong Kong. Sustainability 2017, 9, 1924. [CrossRef]

44. Tian, Y.H.; Liu, Y.Q.; Jim, C.Y.; Song, H.Z. Assessing structural connectivity of urban green spaces in metropolitan Hong Kong. Sustainability 2017, 9, 1653. [CrossRef]

45. Wang, R.; Yuan, Q. Are denser cities greener? Evidence from China, 2000-2010. Nat. Resour. Forum 2017, 41, 179-189. [CrossRef]

46. Wang, J.; Zhou, W.; Wang, J.; Yu, W. Spatial distribution of urban greenspace in response to urban development from a multi-scale perspective. Environ. Res. Lett. 2020, 15, 064031. [CrossRef]

47. Zhang, T.; Chen, S.S.; Li, G. Exploring the relationships between urban form metrics and the vegetation biomass loss under urban expansion in China. Environ. Plan. B Urban Anal. City Sci. 2020, 47, 363-380. [CrossRef]

48. Wellmann, T.; Schug, F.; Haase, D.; Pflugmacher, D.; van der Linden, S. Green growth? On the relation between population density, land use and vegetation cover fractions in a city using a 30-years Landsat time series. Landsc. Urban Plan. 2020, 202, 103857. [CrossRef]

49. Fuller, R.A.; Gaston, K.J. The scaling of green space coverage in European cities. Biol. Lett. 2009, 5, 352-355. [CrossRef] [PubMed]

50. Amaya-Espinel, J.D.; Hostetler, M.; Henriquez, C.; Bonacic, C. The influence of building density on Neotropical bird communities found in small urban parks. Landsc. Urban Plan. 2019, 190, 103578. [CrossRef]

51. Ikin, K.; Beaty, R.M.; Lindenmayer, D.B.; Knight, E.; Fischer, J.; Manning, A.D. Pocket parks in a compact city: How do birds respond to increasing residential density? Landsc. Ecol. 2013, 28, 45-56. [CrossRef]

52. Andersson, E.; Haase, D.; Scheuer, S.; Wellmann, T. Neighbourhood character affects the spatial extent and magnitude of the functional footprint of urban green infrastructure. Landsc. Ecol. 2020, 35, 1605-1618. [CrossRef]

53. Droz, B.; Arnoux, R.; Bohnenstengel, T.; Laesser, J.; Spaar, R.; Aye, R.; Randin, C.F. Moderately urbanized areas as a conservation opportunity for an endangered songbird. Landsc. Urban Plan. 2019, 181, 1-9. [CrossRef]

54. Sushinsky, J.R.; Rhodes, J.R.; Possingham, H.P.; Gill, T.K.; Fuller, R.A. How should we grow cities to minimize their biodiversity impacts? Glob. Chang. Biol. 2013, 19, 401-410. [CrossRef] [PubMed]

55. Sushinsky, J.R.; Rhodes, J.R.; Shanahan, D.F.; Possingham, H.P.; Fuller, R.A. Maintaining experiences of nature as a city grows. Ecol. Soc. 2017, 22. [CrossRef]

56. Soga, M.; Yamaura, Y.; Koike, S.; Gaston, K.J. Land sharing vs. land sparing: Does the compact city reconcile urban development and biodiversity conservation? J. Appl. Ecol. 2014, 51, 1378-1386. [CrossRef]

57. Chau, N.L.; Jim, C.Y.; Zhang, H. Species-specific holistic assessment of tree structure and defects in urban Hong Kong. Urban For. Urban Green. 2020, 55, 126813. [CrossRef]

58. Jim, C.Y. Monitoring the performance and decline of heritage trees in urban Hong Kong. J. Environ. Manag. 2005, 74, 161-172. [CrossRef]

59. Jim, C.Y. Outstanding remnants of nature in compact cities: Patterns and preservation of heritage trees in Guangzhou City (China). Geoforum 2005, 36, 371-385. [CrossRef]

60. Pauleit, S.; Ennos, R.; Golding, Y. Modeling the environmental impacts of urban land use and land cover change-A study in Merseyside, UK. Landsc. Urban Plan. 2005, 71, 295-310. [CrossRef]

61. Pauleit, S.; Golding, Y. The spatial impact of urban compaction: A fine-scale investigation based on Merseyside. Town Plan. Rev. 2006, 76, 143-166. [CrossRef]

62. Whitford, V.; Ennos, A.R.; Handley, J.F. "City form and natural process"—Indicators for the ecological performance of urban areas and their application to Merseyside, UK. Landsc. Urban Plan. 2001, 57, 91-103. [CrossRef]

63. Larondelle, N.; Lauf, S. Balancing demand and supply of multiple urban ecosystem services on different spatial scales. Ecosyst. Serv. 2016, 22, 18-31. [CrossRef]

64. Tratalos, J.; Fuller, R.A.; Warren, P.H.; Davies, R.G.; Gaston, K.J. Urban form, biodiversity potential and ecosystem services. Landsc. Urban Plan. 2007, 83, 308-317. [CrossRef] 
65. Grêt-Regamey, A.; Galleguillos-Torres, M.; Dissegna, A.; Weibel, B. How urban densification influences ecosystem services-A comparison between a temperate and a tropical city. Environ. Res. Lett. 2020, 15, 075001. [CrossRef]

66. Yao, J.; Liu, M.; Chen, N.N.; Wang, X.B.; He, X.Y.; Hu, Y.M.; Wang, X.Y.; Chen, W. Quantitative assessment of demand and supply of urban ecosystem services in different seasons: A case study on air purification in a temperate city. Landsc. Ecol. 2020, 36, 1971-1986. [CrossRef]

67. Verani, E.; Pozoukidou, G.; Sdoukopoulos, A. The effect of urban density, green spaces and mobility patterns in cities' environmental quality: An empirical study of the metropolitan area of Thessaloniki. Spatium 2015, 1, 8-17. [CrossRef]

68. Cho, H.S.; Choi, M.J. Effects of compact Urban development on air pollution: Empirical evidence from Korea. Sustainability 2014, 6, 5968-5982. [CrossRef]

69. Schindler, M.; Caruso, G. Urban compactness and the trade-off between air pollution emission and exposure: Lessons from a spatially explicit theoretical model. Comput. Environ. Urban Syst. 2014, 45, 13-23. [CrossRef]

70. Ye, H.; He, X.Y.; Song, Y.; Li, X.H.; Zhang, G.Q.; Lin, T.; Xiao, L.S. A sustainable urban form: The challenges of compactness from the viewpoint of energy consumption and carbon emission. Energy Build. 2015, 93, 90-98. [CrossRef]

71. Iizuka, S.; Xuan, Y.L.; Takatori, C.; Nakaura, H.; Hashizume, A. Environmental impact assessment of introducing compact city models by downscaling simulations. Sustain. Cities Soc. 2020, 63, 102424. [CrossRef]

72. Koch, F.; Bilke, L.; Helbig, C.; Schlink, U. Compact or cool? The impact of brownfield redevelopment on inner-city micro climate. Sustain. Cities Soc. 2018, 38, 31-41. [CrossRef]

73. Straka, M.; Sodoudi, S. Evaluating climate change adaptation strategies and scenarios of enhanced vertical and horizontal compactness at urban scale (a case study for Berlin). Landsc. Urban Plan. 2019, 183, 68-78. [CrossRef]

74. Arghavani, S.; Malakooti, H.; Ali Akbari Bidokhti, A.A. Numerical assessment of the urban green space scenarios on urban heat island and thermal comfort level in Tehran Metropolis. J. Clean. Prod. 2020, 261, 121183. [CrossRef]

75. Olsen, J.R.; Nicholls, N.; Moon, G.; Pearce, J.; Shortt, N.; Mitchell, R. Which urban land covers uses are associated with residents' mortality A cross-sectional, ecological, pan-European study of 233 cities. BMJ Open 2019, 9, e029555. [CrossRef]

76. Li, C.; Song, Y.; Tian, L.; Ouyang, W. Urban form, air quality, and cardiorespiratory mortality: A path analysis. Int. J. Environ. Res. Public Health 2020, 17, 1202. [CrossRef] [PubMed]

77. Xie, B.; Jiao, J.F.; An, Z.H.; Zheng, Y.L.; Li, Z.G. Deciphering the stroke-built environment nexus in transitional cities: Conceptual framework, empirical evidence, and implications for proactive planning intervention. Cities 2019, 94, 116-128. [CrossRef]

78. Cusack, L.; Sbihi, H.; Larkin, A.; Chow, A.; Brook, J.R.; Moraes, T.; Mandhane, P.J.; Becker, A.B.; Azad, M.B.; Subbarao, P.; et al. Residential green space and pathways to term birth weight in the Canadian Healthy Infant Longitudinal Development (CHILD) Study. Int. J. Health Geogr. 2018, 17, 43. [CrossRef]

79. Brindley, P.; Jorgensen, A.; Maheswaran, R. Domestic gardens and self-reported health: A national population study. Int. J. Health Geogr. 2018, 17, 31. [CrossRef] [PubMed]

80. Mavoa, S.; Davern, M.; Breed, M.; Hahs, A. Higher levels of greenness and biodiversity associate with greater subjective wellbeing in adults living in Melbourne, Australia. Health Place 2019, 57, 321-329. [CrossRef]

81. Kytta, A.M.; Broberg, A.K.; Kahila, M.H. Urban environment and children's active lifestyle: Softgis revealing children's behavioral patterns and meaningful places. Am. J. Health Promot. 2012, 26, e137-e148. [CrossRef] [PubMed]

82. Broberg, A.; Kyttä, M.; Fagerholm, N. Child-friendly urban structures: Bullerby revisited. J. Environ. Psychol. 2013, 35, 110-120. [CrossRef]

83. Wijnands, J.S.; Nice, K.A.; Thompson, J.; Zhao, H.; Stevenson, M. Streetscape augmentation using generative adversarial networks: Insights related to health and wellbeing. Sustain. Cities Soc. 2019, 49, 101602. [CrossRef]

84. Qiu, Y.Z.; Liu, Y.Q.; Liu, Y.; Li, Z.G. Exploring the Linkage between the Neighborhood Environment and Mental Health in Guangzhou, China. Int. J. Environ. Res. Public Health 2019, 16, 3206. [CrossRef]

85. Chum, A.; O'Campo, P.; Matheson, F. The impact of urban land uses on sleep duration and sleep problems. Can. Geogr. 2015, 59, 404-418. [CrossRef]

86. Fransson, U.; Hartig, T. Leisure home ownership and early death: A longitudinal study in Sweden. Health Place 2010, 16, 71-78. [CrossRef]

87. Ihlebæk, C.; Næss, P.; Stefansdottir, H. Are compact cities a threat to public health? Eur. Plan. Stud. 2020, 29, 1021-1049. [CrossRef]

88. Kytta, M.; Broberg, A.; Haybatollahi, M.; Schmidt-Thome, K. Urban happiness: Context-sensitive study of the social sustainability of urban settings. Environ. Plan. B Plan. Des. 2016, 43, 34-57. [CrossRef]

89. Mouratidis, K.; Poortinga, W. Built environment, urban vitality and social cohesion: Do vibrant neighborhoods foster strong communities? Landsc. Urban Plan. 2020, 204, 103951. [CrossRef]

90. Lindal, P.J.; Hartig, T. Effects of urban street vegetation on judgments of restoration likelihood. Urban For. Urban Green. 2015, 14, 200-209. [CrossRef]

91. Masoudinejad, S.; Hartig, T. Window view to the sky as a restorative resource for residents in densely populated cities. Environ. Behav. 2020, 52, 401-436. [CrossRef]

92. Wolsink, M. 'Sustainable City' requires 'recognition'-The example of environmental education under pressure from the compact city. Land Use Policy 2016, 52, 174-180. [CrossRef]

93. Wolsink, M. Environmental education excursions and proximity to urban green space-Densification in a "compact city". Environ. Educ. Res. 2016, 22, 1049-1071. [CrossRef] 
94. Cadieux, K.V. Political ecology of exurban "lifestyle" landscapes at Christchurch's contested urban fence. Urban For. Urban Green. 2008, 7, 183-194. [CrossRef]

95. Arnberger, A. Urban densification and recreational quality of public urban green spaces-A Viennese case study. Sustainability 2012, 4, 703-720. [CrossRef]

96. Lo, A.Y.H.; Jim, C.Y. Citizen attitude and expectation towards greenspace provision in compact urban milieu. Land Use Policy 2012, 29, 577-586. [CrossRef]

97. Coolen, H.; Meesters, J. Private and public green spaces: Meaningful but different settings. J. Hous. Built Environ. 2012, $27,49-67$. [CrossRef]

98. Syme, G.J.; Fenton, D.M.; Coakes, S. Lot size, garden satisfaction and local park and wetland visitation. Landsc. Urban Plan. 2001, 56, 161-170. [CrossRef]

99. Kytta, M.; Broberg, A.; Tzoulas, T.; Snabb, K. Towards contextually sensitive urban densification: Location-based softGIS knowledge revealing perceived residential environmental quality. Landsc. Urban Plan. 2013, 113, 30-46. [CrossRef]

100. Wang, Y.; Kotze, D.J.; Vierikko, K.; Niemela, J. What makes urban greenspace unique-Relationships between citizens' perceptions on unique urban nature, biodiversity and environmental factors. Urban For. Urban Green. 2019, 42, 1-9. [CrossRef]

101. Daams, M.N.; Sijtsma, F.J. How green do we want to live in 2100? Lessons learned from the homes of the present-day rich. Buildings 2017, 7, 97. [CrossRef]

102. Kotulla, T.; Denstadli, J.M.; Oust, A.; Beusker, E. What does it take to make the compact city liveable for wider groups? Identifying key neighbourhood and dwelling features. Sustainability 2019, 11, 3480. [CrossRef]

103. Strandell, A.; Hall, C.M. Impact of the residential environment on second home use in Finland-Testing the compensation hypothesis. Landsc. Urban Plan. 2015, 133, 12-23. [CrossRef]

104. Grosse, J.; Fertner, C.; Carstensen, T.A. Compensatory leisure travel? The role of urban structure and lifestyle in weekend and holiday trips in Greater Copenhagen. Case Stud. Transp. Policy 2019, 7, 108-117. [CrossRef]

105. Czepkiewicz, M.; Klaas, V.; Heinonen, J. Compensation or cosmopolitan attitudes: Explaining leisure travel of Nordic urbanites. Travel Behav. Soc. 2020, 21, 167-187. [CrossRef]

106. Lo, A.Y. Small is green? Urban form and sustainable consumption in selected OECD metropolitan areas. Land Use Policy 2016, 54, 212-220. [CrossRef]

107. Byrne, J.; Ambrey, C.; Portanger, C.; Lo, A.; Matthews, T.; Baker, D.; Davison, A. Could urban greening mitigate suburban thermal inequity?: The role of residents' dispositions and household practices. Environ. Res. Lett. 2016, 11, 045023. [CrossRef]

108. Ambrey, C.; Byrne, J.; Matthews, T.; Davison, A.; Portanger, C.; Lo, A. Cultivating climate justice: Green infrastructure and suburban disadvantage in Australia. Appl. Geogr. 2017, 89, 52-60. [CrossRef]

109. Jim, C.Y.; Chen, W.Y. External effects of neighbourhood parks and landscape elements on high-rise residential value. Land Use Policy 2010, 27, 662-670. [CrossRef]

110. Lo, A.Y.; Jim, C.Y. Willingness of residents to pay and motives for conservation of urban green spaces in the compact city of Hong Kong. Urban For. Urban Green. 2010, 9, 113-120. [CrossRef]

111. Xiao, Y.; Li, Z.G.; Webster, C. Estimating the mediating effect of privately-supplied green space on the relationship between urban public green space and property value: Evidence from Shanghai, China. Land Use Policy 2016, 54, 439-447. [CrossRef]

112. Lin, B.B.; Gaston, K.J.; Fuller, R.A.; Wu, D.; Bush, R.; Shanahan, D.F. How green is your garden?: Urban form and sociodemographic factors influence yard vegetation, visitation, and ecosystem service benefits. Landsc. Urban Plan. 2017, 157, 239-246. [CrossRef]

113. Baro, F.; Calderon-Argelich, A.; Langemeyer, J.; Connolly, J.J.T. Under one canopy? Assessing the distributional environmental justice implications of street tree benefits in Barcelona. Environ. Sci. Policy 2019, 102, 54-64. [CrossRef] [PubMed]

114. Dallimer, M.; Tang, Z.Y.; Bibby, P.R.; Brindley, P.; Gaston, K.J.; Davies, Z.G. Temporal changes in greenspace in a highly urbanized region. Biol. Lett. 2011, 7, 763-766. [CrossRef] [PubMed]

115. Jim, C.Y. Planning strategies to overcome constraints on greenspace provision in urban Hong Kong. Town Plan. Rev. 2002, 73, 127-152. [CrossRef]

116. Jim, C.Y.; Chan, M.W.H. Urban greenspace delivery in Hong Kong: Spatial-institutional limitations and solutions. Urban For. Urban Green. 2016, 18, 65-85. [CrossRef]

117. Anna, K.; Jaan-Henrik, K.; Jakub, K.; Dagmar, H. Ecosystem services in urban land use planning: Integration challenges in complex urban settings-Case of Stockholm. Ecosyst. Serv. 2016, 22, 204-212. [CrossRef]

118. Di Marino, M.; Tiitu, M.; Lapintie, K.; Viinikka, A.; Kopperoinen, L. Integrating green infrastructure and ecosystem services in land use planning. Results from two Finnish case studies. Land Use Policy 2019, 82, 643-656. [CrossRef]

119. Ordonez, C.; Threlfall, C.G.; Livesley, S.J.; Kendal, D.; Fuller, R.A.; Davern, M.; van der Ree, R.; Hochuli, D.F. Decision-making of municipal urban forest managers through the lens of governance. Environ. Sci. Policy 2020, 104, 136-147. [CrossRef]

120. Hautamaki, R. Contested and constructed greenery in the compact city: A case study of Helsinki City Plan 2016. J. Landsc. Archit. 2019, 14, 20-29. [CrossRef]

121. Uggla, Y. Construction of 'nature' in urban planning: A case study of Stockholm. Town Plan. Rev. 2012, 83, 69-85. [CrossRef]

122. Nikolaidou, S.; Kloti, T.; Tappert, S.; Drilling, M. Urban gardening and green space governance: Towards new collaborative planning practices. Urban Plan. 2016, 1, 5-19. [CrossRef] 
123. Tillie, N.; Borsboom-van Beurden, J.; Doepel, D.; Aarts, M. Exploring a stakeholder based urban densification and greening agenda for rotterdam inner city-accelerating the transition to a liveable low carbon city. Sustainability 2018, 10, 1927. [CrossRef]

124. Kozak, D.; Henderson, H.; Mazarro, A.D.; Rotbart, D.; Aradas, R. Blue-Green Infrastructure (BGI) in dense urban watersheds. The case of the Medrano Stream Basin (MSB) in Buenos Aires. Sustainability 2020, 12, 2163. [CrossRef]

125. Jim, C.Y.; Chen, S.S. Comprehensive greenspace planning based on landscape ecology principles in compact Nanjing city, China. Landsc. Urban Plan. 2003, 65, 95-116. [CrossRef]

126. Artmann, M. Urban gray vs. urban green vs. soil protection-Development of a systemic solution to soil sealing management on the example of Germany. Environ. Impact Assess. Rev. 2016, 59, 27-42. [CrossRef]

127. Lai, P.C.; Chen, S.; Low, C.T.; Cerin, E.; Stimson, R.; Wong, P.Y.P. Neighborhood variation of sustainable urban morphological characteristics. Int. J. Environ. Res. Public Health 2018, 15, 465. [CrossRef]

128. Li, Y.; Ma, Q.; Song, Y.; Han, H. Bringing conservation priorities into urban growth simulation: An integrated model and applied case study of Hangzhou, China. Resour. Conserv. Recycl. 2019, 140, 324-337. [CrossRef]

129. Caruso, G.; Cavailhes, J.; Peeters, D.; Thomas, I.; Frankhauser, P.; Vuidel, G. Greener and larger neighbourhoods make cities more sustainable! A 2D urban economics perspective. Comput. Environ. Urban Syst. 2015, 54, 82-94. [CrossRef]

130. Mortberg, U.; Goldenberg, R.; Kalantari, Z.; Kordas, O.; Deal, B.; Balfors, B.; Cvetkovic, V. Integrating ecosystem services in the assessment of urban energy trajectories-A study of the Stockholm Region. Energy Policy 2017, 100, 338-349. [CrossRef]

131. Orsi, F. Centrally located yet close to nature: A prescriptive agent-based model for urban design. Comput. Environ. Urban Syst. 2019, 73, 157-170. [CrossRef]

132. Shoemaker, D.A.; BenDor, T.K.; Meentemeyer, R.K. Anticipating trade-offs between urban patterns and ecosystem service production: Scenario analyses of sprawl alternatives for a rapidly urbanizing region. Comput. Environ. Urban Syst. 2019, 74, 114-125. [CrossRef]

133. Ståhle, A.; Caballero, L. Greening metropolitan growth: Integrating nature recreation, compactness and spaciousness in regional development planning. Int. J. Urban Sustain. Dev. 2010, 2, 64-84. [CrossRef]

134. Artmann, M.; Bastian, O.; Grunewald, K. Using the concepts of green infrastructure and ecosystem services to specify leitbilder for compact and green cities-The example of the landscape plan of Dresden (Germany). Sustainability 2017, 9, 198. [CrossRef]

135. Richter, B.; Behnisch, M. Integrated evaluation framework for environmental planning in the context of compact green cities. Ecol. Indic. 2019, 96, 38-53. [CrossRef]

136. Ahmed, S.; Meenar, M.; Alam, A. Designing a Blue-Green Infrastructure (BGI) network: Toward water-sensitive urban growth planning in Dhaka, Bangladesh. Land 2019, 8, 138. [CrossRef]

137. Daniels, B.; Zaunbrecher, B.S.; Paas, B.; Ottermanns, R.; Ziefle, M.; Ross-Nickoll, M. Assessment of urban green space structures and their quality from a multidimensional perspective. Sci. Total Environ. 2018, 615, 1364-1378. [CrossRef] [PubMed]

138. Gavrilidis, A.A.; Nita, M.R.; Onose, D.A.; Badiu, D.L.; Nastase, I.I. Methodological framework for urban sprawl control through sustainable planning of urban green infrastructure. Ecol. Indic. 2019, 96, 67-78. [CrossRef]

139. Hwang, Y.H.; Jonathan Yue, Z.E. Intended wildness: Utilizing spontaneous growth for biodiverse green spaces in a tropical city. J. Landsc. Archit. 2019, 14, 54-63. [CrossRef]

140. Salata, S.; Giaimo, C.; Barbieri, C.A.; Ballocca, A.; Scalise, F.; Pantaloni, G. The utilization of normalized difference vegetation index to map habitat quality in Turin (Italy). Sustainability 2020, 12, 7751. [CrossRef]

141. Tian, Y.; Jim, C.Y. Factors influencing the spatial pattern of sky gardens in the compact city of Hong Kong. Landsc. Urban Plan. 2011, 101, 299-309. [CrossRef]

142. Tian, Y.H.; Jim, C.Y. Development potential of sky gardens in the compact city of Hong Kong. Urban For. Urban Green. 2012, 11, 223-233. [CrossRef]

143. Tian, Y.H.; Jim, C.Y.; Tao, Y. Challenges and strategies for greening the compact city of Hong Kong. J. Urban Plan. Dev. 2012, 138, 101-109. [CrossRef]

144. Song, X.P.; Tan, H.T.W.; Tan, P.Y. Assessment of light adequacy for vertical farming in a tropical city. Urban For. Urban Green. 2018, 29, 49-57. [CrossRef]

145. Jim, C.Y. Assessing climate-adaptation effect of extensive tropical green roofs in cities. Landsc. Urban Plan. 2015, 138, 54-70. [CrossRef]

146. Yan, J.L.; Zhou, W.Q.; Han, L.J.; Qian, Y.G. Mapping vegetation functional types in urban areas with WorldView-2 imagery: Integrating object-based classification with phenology. Urban For. Urban Green. 2018, 31, 230-240. [CrossRef]

147. Stahle, A. More green space in a denser city: Critical relations between user experience and urban form. Urban Des. Int. 2010, 15, 47-67. [CrossRef]

148. Tan, P.Y.; Rinaldi, B.M. Landscapes for compact cities. J. Landsc. Archit. 2019, 14, 4-7. [CrossRef] 